\title{
Recent developments in materials used for the removal of metal ions from acid mine drainage
}

\author{
Tebogo M. Mokgehle ${ }^{1} \cdot$ Nikita T. Tavengwa ${ }^{1}$
}

Received: 16 April 2020 / Accepted: 17 December 2020 / Published online: 6 February 2021

(C) The Author(s) 2021

\begin{abstract}
Acid mine drainage is the reaction of surface water with sub-surface water located on sulfur bearing rocks, resulting in sulfuric acid. These highly acidic conditions result in leaching of non-biodegradeable heavy metals from rock which then accumulate in flora, posing a significant environmental hazard. Hence, reliable, cost effective remediation techniques are continuously sought after by researchers. A range of materials were examined as adsorbents in the extraction of heavy metal ions from acid mine drainage (AMD). However, these materials generally have moderate to poor adsorption capacities. To address this problem, researchers have recently turned to nano-sized materials to enhance the surface area of the adsorbent when in contact with the heavy metal solution. Lately, there have been developments in studying the surface chemistry of nanoengineered materials during adsorption, which involved alterations in the physical and chemical make-up of nanomaterials. The resultant surface engineered nanomaterials have been proven to show rapid adsorption rates and remarkable adsorption capacities for removal of a wide range of heavy metal contaminants in AMD compared to the unmodified nanomaterials. A brief overview of zeolites as adsorbents and the developent of nanosorbents to modernly applied magnetic sorbents and ion imprinted polymers will be discussed. This work provides researchers with thorough insight into the adsorption mechanism and performance of nanosorbents, and finds common ground between the past, present and future of these versatile materials.
\end{abstract}

Keywords Physically and chemically modified materials $\cdot$ Acid mine drainage $\cdot$ Sorption capacity $\cdot$ Bio-sorbents

\section{Introduction}

Exposure of pyrite $\left(\mathrm{FeS}_{2}\right)$ to oxidative conditions leads to the formation of acidic conditions, resulting in acid mine drainage (AMD). Subsequently, acidic conditions result in leaching of heavy metals into aquatic systems creating an environmental hazard as heavy metals are nonbiodegradable (Ge et al. 2012). Common hazardous heavy metals include, amongst others, $\mathrm{Cr}, \mathrm{Cd}, \mathrm{Cu}, \mathrm{Ni}$ and $\mathrm{U}$ in various oxidation forms ( $\mathrm{Li}$ et al. 2018a, b; Lu et al. 2018; Tavengwa et al. 201a). Heavy metals enter the food chain in a variety of ways, accumulating in living organisms with time (Archary et al. 2017). One of the mechanisms include the high affinity for sulfur which inhibit normal enzyme function by formation of covalent bonds with

Nikita T. Tavengwa

nikita.tavengwa@univen.ac.za

1 Department of Chemistry, School of Mathematical and Natural Sciences, University of Venda, Private Bag X5050, Thohoyandou 0950, South Africa sulfur groups in enzymes. Heavy metals are chemically bound by organic functions such as protein carboxylic acid $(-\mathrm{COOH})$ and amino $\left(-\mathrm{NH}_{2}\right)$. Considering the toxic nature and non-biodegradable characteristics of heavy metals, removal of toxic metals from industrial effluents is essential for the safety of inhabitants.

Remediation of heavy metals in AMD by adsorption has shown to be a productive approach (Sahu et al. 2017; Castro et al. 2018). Generally, adsorption is an inexpensive and useful in comparison to other remediation methods which includes lime neutralization (Othman et al. 2017), carbonate neutralization (Galhardi and Bonotto 2015), ion exchange (Jafaripour and Ghataora 2015; Nordstrom et al. 2015) and metal precipitation (Jafaripour and Ghataora 2015). Some materials studied using this technique include zeolites. These materials and their modified forms have been shown to be very good adsorbents for heavy metals due to their desirable cation exchange properties (Nekhunguni et al. 2017a; Mokgehle et al. 2019). However, zeolites were reported to have setbacks such as poor ion selectivity, for instance, Hui et al. (2005) reported on the

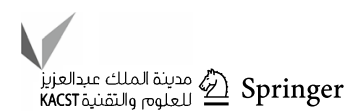


poor adsorption performance of zeolaite-4A in comparison to coal fly ash for removal of $\mathrm{Cu}^{2+}, \mathrm{Cr}^{3+}, \mathrm{Zn}^{2+}, \mathrm{Co}^{2+}$ and $\mathrm{Ni}^{2+}$ from aqueous systems.

In an effort to enhance adsorption performance, researchers focused on nano-sized materials for extraction of heavy metals. One eye-capturing class of adsorbent includes magnetic nanoparticles and its composites; an example includes magnetic graphene oxide composites. Structurally, graphene has a honeycomb arrangement, which significantly improves its surface area. This has led to its various applications as an adsorbent (Cui et al. 2012; Ren et al. 2014; Vilela et al. 2016). Additionally, graphene's versatility allows for functionalization, particularly with carbonyls, hydroxyls and epoxy groups, by oxidation of natural graphite (Gupta et al. 2017; MéndezRomero et al. 2019). Addition of these groups makes graphene oxide sheets hydrophilic and soluble in water (Gupta et al. 2017). However, these materials had setbacks such as poor recyclability, due to its high dispersion in water (Liu et al. 2017).

To address this problem, researchers then focused on introducing physical modifications to graphene oxide nanoparticles by incorporation of magnetic $\mathrm{Fe}_{3} \mathrm{O}_{4}$ nanoparticles (Gugushe et al. 2019). Iron oxide containing materials exhibit useful characteristics such as paramagnetism, biocompatibility, safety, cheap, good adsorption potential and simplicity in separation of the adsorbent from the solution. Despite these advantages, these materials have a tendency of agglomerating and decomposing under acidic conditions resulting in limited adsorption performances. Recently, researchers introduced some modifications which included the use of functional groups such as $\mathrm{NH}_{2}$ or $\mathrm{SH}$ to stabilize $\mathrm{Fe}_{3} \mathrm{O}_{4}$ (Yang et al. 2016).

The use of conventional techniques for treatment of heavy metals due to AMD was reported by Aubé et al. (2003) and Dempsey and Jeon (2001). However, the major drawbacks of conventional remediation approaches range from high operation costs, significant maintenance requirements, poor selectivity, clogging of filtration media to requirements of substantial amounts of remediation materials. Hence, the need for highly selective, efficient and high surface area adsorbents arises. To the best of our knowledge, little is known of a review that summarizes the development of physically and chemically modified zeolites from unmodified zeolites and its utilization for treatment of heavy metal ions in AMD. In this review, an update on advances into usage of iron oxide and metal oxide containing nanomaterials from unmodified nanosorbent are discussed. The development of highly selective ion imprinted polymers (IIP) is also reported. A summary of the adsorption capacities of the nanomaterials for heavy metal ions is presented. Finally, this work highlights some challenges and future perspectives to further bring about attractive developments in this area of water treatment.

\section{Zeolites and chemically modified zeolites as adsorbents for heavy metals in AMD}

Of late, zeolites, as sorbents have caught the attention of most researchers. Chemically, zeolites have the formula $\mathrm{M}_{\mathrm{e} 2 / \mathrm{n}} \mathrm{O} \cdot \mathrm{Al}_{2} \mathrm{O}_{3} \cdot \mathrm{xSiO}_{2} \cdot \mathrm{yH}_{2} \mathrm{O}$ (Mahdi et al. 2017), where $\mathrm{M}_{\mathrm{e}}$ represents first or second group atoms, $\mathrm{n}$ represents atomic charge, $x$ highlights the number of Si tetrahedra $2 \leq x \leq 10$, and $\mathrm{y}$ is the amount of $\mathrm{H}_{2} \mathrm{O}$ molecules $(2 \leq \mathrm{y} \leq 7)$ (Jha and Singh 2016). The zeolite is composed of $\mathrm{SiO}_{4}$ and $\mathrm{AlO}_{4}$ tetrahedra forming a lattice of $\mathrm{Si}$ and $\mathrm{Al}$ centers. The network of $\mathrm{SiO}_{4}$ and $\mathrm{AlO}_{4}$ tetrahedra frequently undergo cation exchange where the $\mathrm{Si}(+4)$ is replaced by $\mathrm{Al}(+3)$ ions, resulting in a net negative charge (Jha et al. 2012; Jha and Singh 2016).

There is a wide literature coverage which demonstrated the application of zeolites in adsorption of heavy metals from AMD (Masukume et al. 2017; Nekhunguni et al. 2017a; Mokgehle et al. 2019; Znedelska et al. 2018; Buenaño et al. 2017; Shabalala and Basitere 2020). For instance, zeolites were evaluated by Turan and Ozgonenel (2013) as $\mathrm{Cu}$ (II) adsorbents through an adaptive neural fuzzy interface system where average adsorption performances were obtained. However, zeolites have often been overwhelmed by setbacks such as early exhaustion of adsorption sites and high expenses associated with the synthesis of the majority of the zeolites. To enhance the adsorption performance, researchers then focused on the utilization of modified or organic coated zeolites (Table 1). In addition to cation exchange, organic coated zeolites adsorb heavy metals through opposite charge based attraction. This enhancement is due to the presence of charged organic groups on the surface of the zeolite (Mokgehle et al. 2019). Though the inclusion of organic moieties improved the removal efficiencies of zeolites, these materials still exhibit moderate heavy metal removal efficiencies as a result of their low surface area in the sample solution. Hence, researchers have of late turned their interests to nano-sized materials as potential adsorbents for heavy metal remediation in AMD.

\section{Nanosorbents}

Adsorption is known to be an environmentally, ecologically and green method for the removal of toxic metal(s) from contaminated solution. Adsorption is a versatile technique, in the sense that the adsorbent can be restored and subsequently re-used without reducing the removal efficiency (Bai et al. 2017). A range of adsorbents for treatment of AMD have been used, which include high density 
Table 1 Modified zeolites applied for adsorption of AMD associated heavy metals

\begin{tabular}{llcll}
\hline Modified zeolite & Target metal(s) & $\begin{array}{l}\text { Sorption capacity } \\
\left(\mathrm{mg} \mathrm{g}^{-1}\right)\end{array}$ & $\begin{array}{l}\text { Removal effi- } \\
\text { ciency (\%) }\end{array}$ & Reference \\
\hline Iron (hydr) oxide & $\mathrm{As}(\mathrm{V})$ & 1.69 & - & Nekhunguni et al. (2017a) \\
Oxalic acid & $\mathrm{Cd}$ (II) & - & 46.68 & Mokgehle et al. (2019) \\
Succinic acid & $\mathrm{Cd}$ (II) & - & 46.57 & Mokgehle et al. (2019) \\
Adipic acid & $\mathrm{Cd}$ (II) & - & 46.64 & Mokgehle et al. (2019) \\
DCMD & $\mathrm{Fe}$ (II) & 62.11 & - & Ryu et al. (2019) \\
DCMD & $\mathrm{Al}$ (II) & 44.64 & - & Ryu et al. (2019) \\
DCMD & $\mathrm{Zn}$ (II) & 39.96 & - & Ryu et al. (2019) \\
HFOMZ & $\mathrm{U}$ (VI) & 0.24 & - & Nekhunguni et al. (2017b) \\
\hline
\end{tabular}

*DCMD-submerged direct contact membrane distillation, HFOMZ-hydrous ferric oxide-modified zeolite sludge (Sukati et al. 2018; Dlamini et al. 2019), alkali-barium-calcium (Mulopo and Motaung 2014; Akinwekomi et al. 2017), coal fly ash (Rios et al. 2008; Madzivire et al. 2019) and lignite (Mohan and Chander 2006; Karagüzel et al. 2020). Among the studied adsorbents is activated carbon (Hong et al. 2017), silica (Etale et al. 2016; Lakovleva and Sillanpää 2013) and ferric oxide (Dlamini et al. 2019). The major shortfall of activated carbon nanosorbents is that they are expensive to use and laborious to isolate from wastewater after application. Naturally derived materials such as banana peels have also been investigated as sorbents for the removal of heavy metal ions. For example, Castro et al. (2011) studied the use of banana peels (particle size 35-45 mm) for $\mathrm{Cu}$ adsorption from aqueous solution and obtained an adsorption capacity of $20 \mathrm{mg} \mathrm{g}^{-1}$. However, the macroscale materials studied by Castro et al. (2011) had low surface area and were responsible for low adsorption performances as argued by Bakiya and Sudha (2012) and Ashok et al. (2010). As a result, researchers have now directed their attention to a unique class of materials in the form of nanomaterials. These materials permit for more active sites with increased surface area and can display novel properties which can be applied in the design of new heavy metal treatment methods and improvement of current ones (Bakiya and Sudha 2012). The surface chemistry of the adsorbent is an important parameter that determines extent of adsorption. For instance, the acicular goethite nanoparticles studied by Moreira et al. (2017) were found to be effective for the removal of As (V) from AMD and was attributed to its acidic point of zero charge $\mathrm{pH}_{\mathrm{pzc}}=3.5$. This was further indicated in the same study that the net charge of the sorbent above $\mathrm{pH}=3.5$ was negative and facilitated adsorption of cationic heavy metals from AMD. However, the surface charge may not be the only determining factor, for example Rodríguez et al. (2020) evaluated graphene oxide and graphene oxide with zinc nanoparticles (GO-ZnO) nanocomposites with $\mathrm{pH}_{\mathrm{pzc}}=3.98$ and $\mathrm{pH}_{\mathrm{pzc}}=5.57$, respectively, and observed that the latter adsorbent had a better adsorption capacity for $\mathrm{Al}$ and $\mathrm{Cu}$. Theoretically, in the same study, it was expected that the GO nanocomposite would be a better sorbent for heavy metals due to its negatively charged surface at a relatively lower $\mathrm{pH}$ to $\mathrm{GO}-\mathrm{ZnO}$. However, functionalization with $\mathrm{ZnO}$ seemed to have played a greater role in adsorption under AMD simulated conditions. Another factor, pore size, was shown to play a role in influencing the selectivity of heavy metals in AMD. Etale et al. (2017) evaluated mesoporous silica nanoparticles and reported that possible configurational advantages of Mn (II) lead to its better adsorption than $\mathrm{Cu}$ (II). Similar trends on the influence of pore size were also reported by Nqombolo et al. (2019) and Dlamini et al. (2019). Table 2 shows the adsorption capacities of some recently studied nano-materials. The nanosorbents studied ranged from bio-materials such as banana peels, microrganisms (fungi) to inorganic carbon composites.

Iron oxide containing materials, maghemite nanosorbent was evaluated by Etale et al. (2016) in multicomponent system for the adsorption of heavy metals, The adsorption efficiencies in the same study was observed to increase in the following order $\mathrm{U}<\mathrm{Mn}<\mathrm{Cu}$. Furthermore, in the same study, factors such as competition from $\mathrm{H}^{+}$and changes in adsorption surface charge were reported to have an influence on the adsorption performance. Oyewo et al. (2018) reported on the application of nanosorbent banana peels for removal of lanthanides compounds from acid mine water. It was concluded from the study (Oyewo et al. 2018) that a high surface area and particle size reduction improved banana peels sorption capacity for removal of radioactive lathanides from synthetic and real mine water. Another class of nanoparticles involving metal oxides include metal oxide nanoparticles (MONPs) and is desired for its high adsorption capacity (Masoumi et al. 2019; Xu et al. 2018). Moreover, in the majority of cases, the metal oxide nanoparticles' surfaces are amphoteric indicating that it can function as either electron donors or acceptors (Wang et al. 2019a, b). Another study on MONPs was conducted by Gugushe et al. (2019) where poor adsorption capacities were obtained. Probably

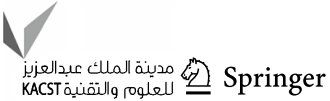


Table 2 Adsorption capacities of some studied nanoparticles for heavy metals in AMD

\begin{tabular}{|c|c|c|c|}
\hline Nanoparticle & Target metal(s) & $\begin{array}{l}\text { Sorption capacity } \\
\left(\mathrm{mg} \mathrm{g}^{-1}\right)\end{array}$ & Reference \\
\hline \multirow[t]{2}{*}{ Banana peels } & $\mathrm{La}$ & 47.8 & \multirow[t]{2}{*}{ Oyewo et al. (2018) } \\
\hline & $\mathrm{Gd}$ & 52.6 & \\
\hline MWCNT-Fe ${ }_{2} \mathrm{O}_{3} @ \mathrm{Zeo}$ & As (III) & 20.4 & Gugushe et al. (2019) \\
\hline \multirow[t]{3}{*}{ Hap $\left(\mathrm{g}-\mathrm{C}_{3} \mathrm{~N}_{4}\right)$} & $\mathrm{Zn}(\mathrm{II})$ & 230 & \multirow[t]{3}{*}{ Beygli et al. (2019) } \\
\hline & $\mathrm{Pb}$ (II) & 130 & \\
\hline & $\mathrm{Mn}(\mathrm{II})$ & 260 & \\
\hline Fungi & Ni (II) & 97.7 & Shakya et al. (2018) \\
\hline \multirow[t]{3}{*}{ Maghemite } & $\mathrm{Cu}$ (II) & 108.7 & \multirow[t]{3}{*}{ Etale et al. (2016) } \\
\hline & Mn (II) & 208.3 & \\
\hline & U (III) & 20.3 & \\
\hline \multirow[t]{3}{*}{ ZSNZVI } & As (II) & 12.84 & \multirow[t]{3}{*}{ Li et al. $(2018 a, b)$} \\
\hline & Cd (II) & 62.02 & \\
\hline & $\mathrm{Pb}(\mathrm{II})$ & 85.90 & \\
\hline $\mathrm{HNO}_{3}$-treated $\mathrm{MCN}$ & $\mathrm{Ni}$ (II) & 17.86 & Mobasherpour et al. (2012) \\
\hline Br-PADAP & $\mathrm{U}(\mathrm{VI})$ & 87.38 & Khamirchi et al. (2018) \\
\hline OS & $\mathrm{Cr}(\mathrm{VI})$ & 1.48 & Vilardi et al. (2018) \\
\hline OS-nZVI & $\mathrm{Cr}(\mathrm{VI})$ & 2.54 & Vilardi et al. (2018) \\
\hline OS-nMG & $\mathrm{Cr}(\mathrm{VI})$ & 4.11 & Vilardi et al. (2018) \\
\hline MPTS mesoporous silica & $\mathrm{Hg}(\mathrm{I})$ & 479 & Yan et al. (2019) \\
\hline
\end{tabular}

Magnetic multi-walled carbon nanotubes@zeolite $\left(\mathrm{MWCNT}-\mathrm{Fe}_{2} \mathrm{O}_{3} @ \mathrm{Zeo}\right)$, Hydroxyapatite modified graphitic carbon nitrite (Hap $\left(\mathrm{g}-\mathrm{C}_{3} \mathrm{~N}_{4}\right)$, Zeolite-supported nanoscale zero-valent iron (ZSNZVI), Nitric acid treated multiwalled carbon nanotubes $\left(\mathrm{HNO}_{3}\right.$-treated (MCN)), 2-(5-Bromo-2-pyridylazo)-5-(diethylamino) phenol impregnated on multiwall carbon nanotubes (Br-PADAP MWCNTs), Olive stone-Nanozero-valent iron and carbon nanotubes composite (OS-ZVI), Calcined Magnesium Aluminium hydroxides-(Cal. $\mathrm{MgAl} \mathrm{OH})$ problems such as agglomeration which leads the nanoparticles to have a reduction in its nano-intergrity, contributed to the inefficient adsorption performance (Gugushe et al. 2019).

The majority of the interactions between the nanomaterials and the adsorbent of interest involve electrostatic interaction. For example, below the point of zero charge of the nanosorbent, physical adsorption is dominant whereas above the point of zero charge electrostatic interaction becomes more prominent as shown in Fig. 1 (Nqombolo et al. 2019).

This claim is supported by the results obtained by Beygli et al. (2019) who also observed that adsorption of AMD derived heavy metals such as $\mathrm{Cu}^{2+}, \mathrm{Zn}^{2+}$ and $\mathrm{Pb}^{2+}$ onto hydroxyapatite modified graphitic carbon nitrite (Hap $\left(\mathrm{g}-\mathrm{C}_{3} \mathrm{~N}_{4}\right.$ ) could be re-used for up to 12 cycles. Similarly, Vilardi et al. (2018) observed that the olive stones coated with iron-based nanoparticles could be used for up to 5 times.

Magnetic multi-walled carbon nanotubes@zeolite (MWCNT-Fe ${ }_{2} \mathrm{O}_{3} @ Z e o$ ), Hydroxyapatite modified graphitic carbon nitrite (Hap $\left(\mathrm{g}-\mathrm{C}_{3} \mathrm{~N}_{4}\right.$ ), Zeolite-supported nanoscale zero-valent iron (ZSNZVI), Nitric acid treated multiwalled carbon nanotubes $\left(\mathrm{HNO}_{3}\right.$-treated $\left.(\mathrm{MCN})\right)$, 2-(5-Bromo-2pyridylazo)-5-(diethylamino)phenol impregnated on multiwall carbon nanotubes (Br-PADAP MWCNTs), Olive
stone-Nanozero-valent iron and carbon nanotubes composite (OS-ZVI), Calcined Magnesium Aluminium hydroxides(Cal. $\mathrm{MgAl} \mathrm{OH})$.

\section{Magnetic sorbents}

Nanosized materials exhibiting magnetic properties have attracted interest among researchers. These novel class of materials exhibit desired properties such as high surface area and superparagmagnetism, which result in high adsorption efficiency and high removal rate of contaminants and fast separation of adsorbent from contaminated solution using an external magnetic field which is a major setback of nonmagnetic nanosorbent materials (Chowdhury and Yanful 2010). To circumvent this problem, researchers focused on altering the magnetic properties by incorporating iron oxides such as magnetite $\left(\mathrm{Fe}_{3} \mathrm{O}_{4}\right)$ and maghemite $\left(\mathrm{g}-\mathrm{Fe}_{2} \mathrm{O}_{3}\right)$ to improve separation from the solution and the adsorption capacity. Briso et al. (2018) reported on good separation of the magnetic coated $\mathrm{Fe}_{3} \mathrm{O}_{4}$ nanostructured calcium silicate hydrate (mag-NanoCSH) and manganese oxide (mag$\mathrm{MnO}_{2}$ ) from solution. It was noted that the presence of iron in the nanosorbent had a major role in the removal of As through formation of water insoluble and stable double iron 

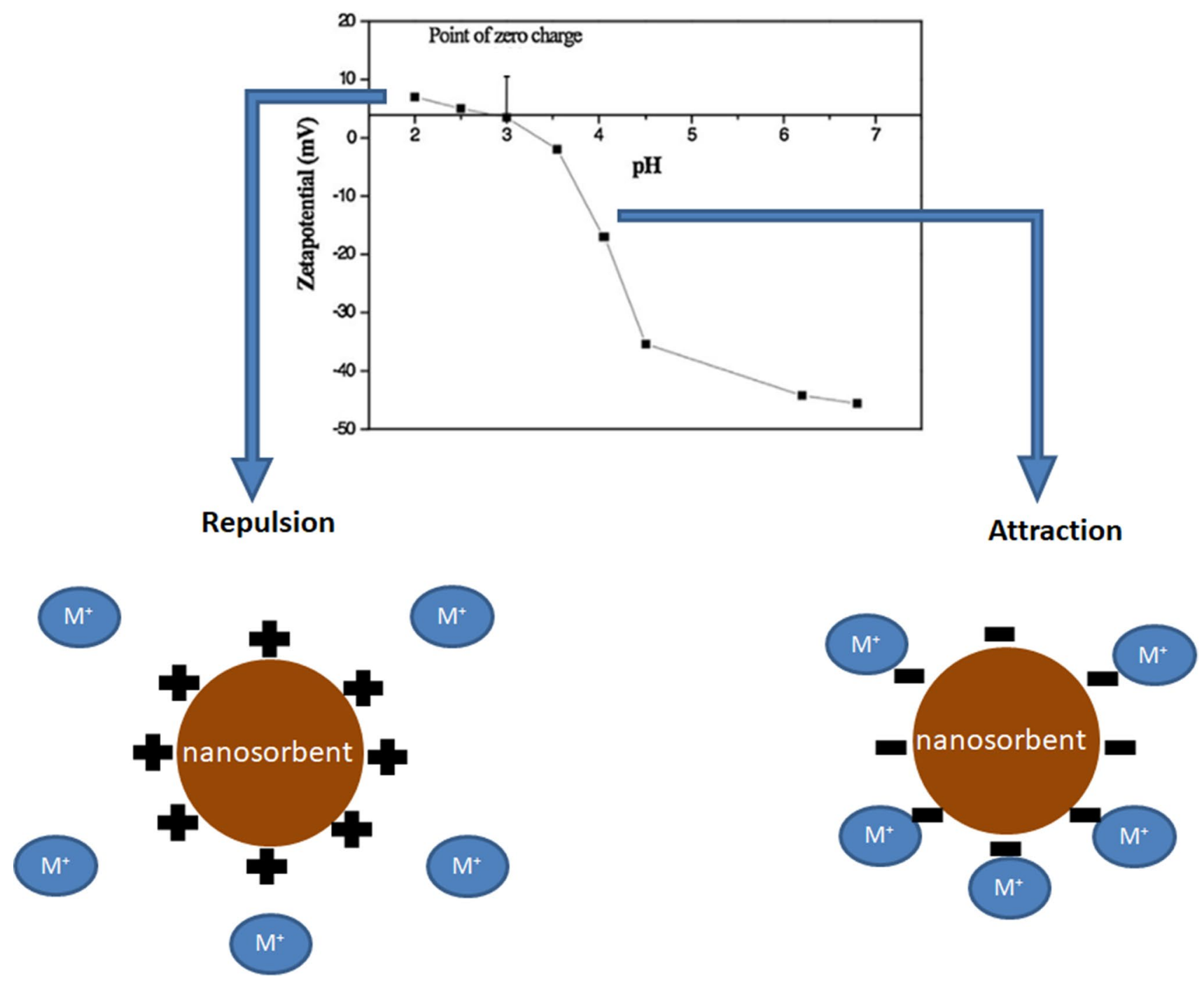

Fig. 1 Repulsion and attraction of a heavy metal $\left(\mathrm{M}^{+}\right)$occurring below and above the point the point of zero charge on the surface of the nanosorbent, respectively

and calcium arsenate salts (Briso et al. 2018). In another study, Barrera et al. (2017) reported nanostructured calcium silicate hydrate, unmodified or modified with Fe (III), for removal of heavy metals such as $\mathrm{Cd}$ (II), $\mathrm{Cu}$ (II) and $\mathrm{Zn}$ (II) from acidic aqueous solutions. Some of the studied magnetic nanosorbents are shown in Table 3. Several studies on adsorption of highly toxic compounds such as $\mathrm{Hg}$ (II) and $\mathrm{Cd}$ (II) have been done using functionalized magnetic nanoparticles as seen with the study by Maia et al. (2019). The authors reported nanoparticles that L-cysteine functionalized oxyhydroxide (Cys- $\delta$-FeOOH) had a greater adsorption capacity than $\delta-\mathrm{FeOOH}$ to a lower point of zero charge for Cys- $\delta$-FeOOH, permitting for greater adsorption of $\mathrm{Hg}$ (II). Additionally, one of the highest reported adsorption capacities is that for chitosan functionalized nanoparticles (CMNP) as studied by Christopher et al. (2017), which was also a functionalized magnetic nanoadsorbent (Table 3). Multicomponent studies were also evaluated for these magnetic sorbents, for instance the adsorption onto carboxylated magnetic iron oxide nanoparticles as studied by Xu et al. (2019) was shown to follow the order $\mathrm{Cd}^{2+}>\mathrm{Cu}^{2+}>\mathrm{Pb}^{2+}>\mathrm{Ni}^{2+}$. An additional feature of these compounds is their regeneration capability. Adsorption of heavy metals to the iron oxide coated sorbent is a $\mathrm{pH}$ dependant process, the used nanosorbent can be regenerated by adjusting the $\mathrm{pH}$ (Gugushe et al. 2019). Several studies indicated that even after the regeneration process, the adsorption capacity is maintained (Badruddoza et al. 2013; Gugushe et al. 2019). 
Table 3 Adsorption capacities of some studied nanoparticles for heavy metals in AMD

\begin{tabular}{|c|c|c|c|}
\hline Magnetic nanoparticle & Target metal(s) & $\begin{array}{l}\text { Sorption capac- } \\
\text { ity }\left(\mathrm{mg} \mathrm{g}^{-1}\right)\end{array}$ & Reference \\
\hline \multirow[t]{2}{*}{ Acac-C@ $\mathrm{Fe}_{3} \mathrm{O}_{4}$} & $\mathrm{Hg}$ (II) & 98.0 & Ma et al. (2019) \\
\hline & $\mathrm{Cr}(\mathrm{III})$ & 151 & \\
\hline \multirow[t]{3}{*}{$\mathrm{Cu}(\mathrm{tpa}) . \mathrm{GO}$} & $\mathrm{Cu}$ (II) & 180 & Rahimi and Mohaghegh (2017) \\
\hline & $\mathrm{Cd}(\mathrm{II})$ & 95 & \\
\hline & $\mathrm{Fe}(\mathrm{II})$ & 110 & \\
\hline CNZVI & $\mathrm{Cd}$ (II) & 124 & Lu et al. (2015) \\
\hline $\mathrm{Fe}_{3} \mathrm{O}_{4}$ & As (III) & 0.70 & Sahu et al. (2017) \\
\hline CMNP & $\mathrm{Pb}(\mathrm{II})$ & 498 & Christopher et al. (2017) \\
\hline $\mathrm{Fe}_{3} \mathrm{O}_{4}-\mathrm{CS} @ \mathrm{BT}$ & $\mathrm{Cr}(\mathrm{VI})$ & 62.1 & Feng et al. (2019) \\
\hline$\delta-\mathrm{FeOOH}$ & $\mathrm{Hg}$ (II) & 35.0 & Maia et al. (2019) \\
\hline Cys- $\delta-\mathrm{FeOOH}$ & $\mathrm{Hg}(\mathrm{II})$ & 217 & \\
\hline \multirow[t]{2}{*}{$\mathrm{Fe}_{3} \mathrm{O}_{4} @ \mathrm{EDTA}$} & $\mathrm{Ag}(\mathrm{I})$ & 71.0 & Ghasemi et al. (2017) \\
\hline & $\mathrm{Cd}$ (II) & 169 & \\
\hline \multirow[t]{4}{*}{ MNP-COOH } & $\mathrm{Pb}$ (II) & 177 & Xu et al. (2019) \\
\hline & $\mathrm{Cu}$ (II) & 41.9 & \\
\hline & $\mathrm{Cd}$ (II) & 58.2 & \\
\hline & $\mathrm{Ni}(\mathrm{II})$ & 25.8 & \\
\hline $\mathrm{Fe}_{3} \mathrm{O}_{4} @ \mathrm{CMC} @ \mathrm{ZIF}-8-\mathrm{OH}$ & $\mathrm{Rb}(\mathrm{I})$ & 109 & Tian et al. (2019) \\
\hline \multirow[t]{2}{*}{ MAC/clay composite } & $\mathrm{Cu}$ (II) & 96.1 & Le et al. (2019) \\
\hline & $\mathrm{Ni}(\mathrm{II})$ & 84.8 & \\
\hline \multirow[t]{4}{*}{$\mathrm{Fe}_{3} \mathrm{O}_{4} @ \mathrm{APS} @ \mathrm{AA}-\mathrm{co}-\mathrm{CA}$ MNPs } & $\mathrm{Cd}$ (II) & 29.6 & Ge et al. (2012) \\
\hline & $\mathrm{Zn}$ (II) & 43.4 & \\
\hline & $\mathrm{Pb}(\mathrm{II})$ & 166 & \\
\hline & $\mathrm{Cu}$ (II) & 126 & \\
\hline \multirow[t]{2}{*}{ Tannic- $\mathrm{Ni}_{0.6} \mathrm{Fe}_{2.4} \mathrm{O}_{4}$} & $\mathrm{~Pb}(\mathrm{II})$ & 139.8 & Wang et al. (2019a, b) \\
\hline & $\mathrm{Cu}$ (II) & 70.7 & \\
\hline IO-NPs & $\mathrm{Cu}$ (II) & 188 & Ercan et al. (2019) \\
\hline $\mathrm{Fe}_{3} \mathrm{O}_{4} @ \mathrm{SiO}_{2} @ \mathrm{PEI}-\mathrm{NTDA}$ & $\mathrm{Pb}$ (II) & 285 & Jia et al. (2019) \\
\hline
\end{tabular}

*Chitosanstabilized nanozero-valent iron (CNVI), Magnetic $\mathrm{Fe}_{3} \mathrm{O}_{4}$-chitosan@bentonite $\left(\mathrm{Fe}_{3} \mathrm{O}_{4} @ \mathrm{BT}\right)$, Superparamagnetic iron oxide (SPION), L-cysteine functionalized oxyhydroxide (Cys- $\delta$-FeOOH), Acetylacetone functionalized magnetic carbon microspheres (Acac-C@ $\mathrm{Fe}_{3} \mathrm{O}_{4}$ ), Chitosan functionalized nanoparticles (CMNP), Carboxymethyl cellulose (CMC), Magnetic acitivated carbon nano particles (MACP), $\mathrm{Fe}_{3} \mathrm{O}_{4} @ \mathrm{SiO}_{2}$ nanoparticles with polyethylenimine and 1,4,5,8-naphthalenetetracarboxylic- dianhydride, $\left(\mathrm{Fe}_{3} \mathrm{O}_{4} @ \mathrm{SiO}_{2} @\right.$ PEI-NTDA), Iron oxide nanoparticles (IO-NPs), Biogenic iron compound $\left(\mathrm{FeCO}_{3} / \mathrm{Fe}_{3} \mathrm{O}_{4} /\right.$ $\mathrm{Fe}_{3}\left(\mathrm{PO}_{4}\right)_{2} \cdot 8 \mathrm{H}_{2} \mathrm{O}$ ), magnetic activated carbon/clay composite (MAC/clay composite), $\mathrm{Fe}_{3} \mathrm{O}_{4}$ magnetic nanoparticles (MNPs) modified with 3-aminopropyltriethoxysilane (APS) and copolymers of acrylic acid (AA) and crotonic acid (CA) $\left(\mathrm{Fe}_{3} \mathrm{O}_{4} @\right.$ APS @AA-co-CA MNPs), Tannic-functionalized nickel-iron oxide (Tannic- $\mathrm{Ni}_{0.6} \mathrm{Fe}_{2.4} \mathrm{O}_{4}$ ), Iron oxide nanoparticles (IO-NPs)

\section{lon imprinted polymers as adsorbents}

Ion imprinted polymers (IIPs) are highly distinguished materials. Some of the attractive features of IIPs include thermal stability (Ren et al. 2008), the potential to segregate and preconcentrate the analyte from other competing ions (Darroudi et al. 2020). This has led to the substantial usage of IIPs in separation methods and membrane based technologies (Piletsky et al. 1999; Lu et al. 2018; Sun et al. 2017), this includes solid phase extraction (Hennion 1999; Zhu et al. 2019), the production of sensors (Prasad and Jauhari 2015; Bojdi et al. 2015) and as stationary phases in high performance liquid chromatography (Bitas and Samanidou 2020). The design of IIPs is adopted from that of molecularly imprinted polymers (MIPs), the imprinted regions imitate the 'lock and key' mechanism of enzymes, in selective extraction or removal of the ion template(s) in the presence of competing ions. Other researchers evaluated eco-friendly IIPs through the inclusion of chitosan sorbent structure. $\mathrm{Li}$ et al. (2019) looked at mixed solutions of Pd (II) and Cd (II) for adsorption onto double-imprinted electrospun crosslinked chitosan nanofibers ( $\mathrm{Pd} / \mathrm{Cd}$-DIECCNs) and reported adsorption capacities of 567 and $371 \mathrm{mg} \mathrm{g}^{-1}$ for Pd (II) and Cd (II), respectively. Similarly IIPs bio-nanomaterials were 
Table 4 Adsorption capacities of reported ion imprinted nanosorbents

\begin{tabular}{|c|c|c|c|}
\hline Ion imprinted polymer(IIP) & Target metal(s) & $\begin{array}{l}\text { Sorption capacity } \\
\left(\mathrm{mg} \mathrm{g}^{-1}\right)\end{array}$ & Reference \\
\hline $\mathrm{Pb}-\mathrm{Cs}$ IIP & $\mathrm{Pb}$ (II) & 136 & Gatabi et al. (2020) \\
\hline NIP & $\mathrm{Ni}$ (II) & 125 & Kumar et al. (2019) \\
\hline \multirow[t]{2}{*}{$\mathrm{Pd} / \mathrm{Cd}-\mathrm{DIECCNs}$} & $\mathrm{Pd}(\mathrm{II})$ & 567 & Li et al. (2019) \\
\hline & $\mathrm{Cd}$ (II) & 341 & \\
\hline $\mathrm{Ag}^{+}-$PHEMAC & $\operatorname{Ag}(\mathrm{I})$ & 49.3 & Şarkaya et al. (2019) \\
\hline Fe(III)-IIP & $\mathrm{Fe}(\mathrm{III})$ & 114 & Zhu et al. (2019) \\
\hline Pb-IIPs & $\mathrm{Pb}$ (II) & 49.5 & Balouch et al. (2019) \\
\hline IIP-MAA & Co (II) & 106 & Yosuf et al. (2019) \\
\hline Sm(III)-IIP & Sm (III) & 14.9 & Masoumi et al. (2019) \\
\hline Co-IIP & Co (II) & 95.4 & Biswas et al. (2019) \\
\hline $\mathrm{Cu}-\mathrm{IIP}$ & Cd (II) & 103 & Biswas et al. (2019) \\
\hline NiIMS1 & Ni (II) & 22.9 & He et al. (2018) \\
\hline NiIMS2 & $\mathrm{Ni}$ (II) & 20.8 & He et al. (2018) \\
\hline G-HQ-C IIPs & $\mathrm{Cu}(\mathrm{II})$ & 111 & Wang et al. (2019a, b) \\
\hline $\mathrm{Co}(\mathrm{II})-\mathrm{IIP}$ & Co (II) & 175 & Yuan et al. (2018) \\
\hline IIMMs & $\mathrm{Li}(\mathrm{I})$ & 27.1 & Sun et al. (2017) \\
\hline $\mathrm{Cr}(\mathrm{VI}) \mathrm{IIP}$ & $\mathrm{Cr}(\mathrm{VI})$ & 56.1 & $\begin{array}{l}\text { Taghizadeh and Has- } \\
\text { sanpour (2017) }\end{array}$ \\
\hline $\mathrm{IIP} @ \mathrm{SiO}_{2} @ \mathrm{Fe}_{3} \mathrm{O}_{4}$ & As (V) & 104.7 & Sadani et al. (2020) \\
\hline
\end{tabular}

$\mathrm{Pb}-\mathrm{Cs}$ (Chitosan lead ion imprinted polymer network), NIP (Nickel imprinted polymers), Pd-ATU (Pallidium allyl thiourea), $\mathrm{Pd} / \mathrm{Cd}$-DIECCNs ( $\mathrm{Pb}$ (II)-Cd(II) double-imprinted electrospun crosslinked chitosan nanofibers), $\mathrm{Ag}^{+}$-imprinted PHEMAC poly(hydroxyethylmethacrylate-N-methacryloyl-L-cysteine, Ni-SC (Ni(II) ions imprinted seaweed-chitosan), CA/CS IM (Cellulose acetate /Cellulose Chitosan imprinted membrane), NIP- Nickel ion imprinted polymer, $\mathrm{Ni}^{2+}$ imprinted mesoporous organosilica materials (NiIMS1) and MCM-41 (NiIMS2)), G-HQ-C IIPs (eco-friendly gelatin (G), 8-hydroxyquinoline (HQ) and chitosan (C) ion imprinted polymers), ion imprinted macroporous membranes (IIMMs) IIP@ $\mathrm{SiO}_{2} @ \mathrm{Fe}_{3} \mathrm{O}_{4}$ reported by Xu et al. (2015) and Gatabi et al. (2020). Lately, further upgrades on chitosan containing IIPs have been made to better selectivity and adsorption efficiency (Pakdel and Peighambardoust 2018). Shakerian et al. (2016) evaluated chistosan based IIPs in solid-phase extraction of lead ions. Moreover, chitosan containing IIPs have also been described as useful scavengers of trace metals in conditions were matrix effects tend to limit the adsorption process (Zhang et al. 2015, 2019). Besides the advantages of IIPs, these materials also come with various constraints in particular; deeply placed imprinted cavities which make binding regions beyond reach; poor extraction of template bound analyte ions; reduced transfer of analyte ions, non-uniform binding spots and template bleeding. Hence, researchers, in an effort to improve adsorption and selectivity of target ions, focused on surface based IIPs (Jia et al. 2018; Masoumi et al. 2019; Tavengwa et al. 2015b). Similarly, Zheng et al. (2020) evaluated surface IIPs nanocrystals in adsorption of Dy (III) and achieved adsorption capacities of $22.57-34.03 \mathrm{mg} \mathrm{g}^{-1}$. Not much, to date, is known on the regeneration of IIPs for adsorption of heavy metals, however a study by Sadani et al. (2020) evaluated the recyclability of IIP@ $\mathrm{SiO}_{2} @ \mathrm{Fe}_{3} \mathrm{O}_{4}$ and reported that this material could be re-used for up to four times for adsorption of As (V). More examples of the application of IIPs as heavy metal adsorbents are given in Table 4.

$\mathrm{Pb}-\mathrm{Cs}$ (Chitosan lead ion imprinted polymer network), NIP (Nickel imprinted polymers), Pd-ATU (Pallidium allyl thiourea), $\mathrm{Pd} / \mathrm{Cd}$-DIECCNs (Pb(II)-Cd(II) doubleimprinted electrospun crosslinked chitosan nanofibers), $\mathrm{Ag}^{+}$-imprinted PHEMAC poly(hydroxyethylmethacrylate$\mathrm{N}$-methacryloyl-L-cysteine, Ni-SC (Ni(II) ions imprinted seaweed-chitosan), CA/CS IM (Cellulose acetate/Cellulose Chitosan imprinted membrane), NIP- Nickel ion imprinted polymer, $\mathrm{Ni}^{2+}$ imprinted mesoporous organosilica materials (NiIMS1) and MCM-41 (NiIMS2)), G-HQ-C IIPs (ecofriendly gelatin $(\mathrm{G}), 8$-hydroxyquinoline (HQ) and chitosan (C) ion imprinted polymers), ion imprinted macroporous membranes (IIMMs) IIP@ $\mathrm{SiO}_{2} @ \mathrm{Fe}_{3} \mathrm{O}_{4}$.

\section{Conclusion}

Over the past several decades, environmental laws set by WHO and other environmental monitoring bodies have become stricter, necessitating compliance with acceptable 
concentrations of contaminants in water, particularly heavy metals. Hence, intensive research was undertaken to investigate suitable remediation methods for AMD derived heavy metals. Of the techniques studied, the adsorption technique was proven to be a popular technique due to its simplicity, affordability and reusability of the material. Typical desirable adsorbents such as nanosorbents exhibit high ion exchange capacity, high porosity, large surface area and adequate specific adsorption sites. Conventional materials, such as zeolites do not adequately satisfy the desired characteristics of typical adsorbents. This review paper provided a current perspective of an emerging class of nanosorbents. These included nanomaterials such as chemically modified iron oxide $\left(\mathrm{Fe}_{2} \mathrm{O}_{3}\right)$ magnetic adsorbents which have shown to have superior adsorbent characteristics in comparison to unmodified nanomaterials, in that they permit for ease of separation of adsorbent from the analyte solution. Lately, a more versatile class of nanosorbents in ion imprinted polymers have attracted immense interest due to its high selectivity and its ability to preconcentrate heavy metal ions present in trace concentrations or from complex matrices.

\section{Challenges and future perspectives}

A major setback of nanomaterials is the tendency to form agglomerates in the aqueous solution through various surface forces, limiting the adsorption capacity. Hence, small scale nano-engineering studies investigating the surface chemistry of nanomaterial by incorporating function groups such as $-\mathrm{OH},-\mathrm{NH}_{2}$ and $-\mathrm{COOH}$ have been done with the aim of reducing the extent of agglomeration. Another limitation of nanomaterials particularly metal oxides, is their toxicity in the analyte solution. This implies that large scale application of metal oxide nanosorbents for treatment of heavy metals in AMD could result in cytotoxicity and DNA damage to plants and microorganisms. For instance, studies indicate that gram negative bacteria are susceptible to metal oxide nanomaterials such as ZnO (Dimapilis et al. 2018; Mirza et al. 2019). Additionally, 21 virulence genes of Legionella pneumophila were observed to down-regulate after exposure to $\mathrm{CuO}$ nanoparticles (Mou and Leung 2017). Furthermore, Escherichia coli when exposed to gold nanoparticles were found to down regulate the energy-metabolism and transcription (Cui et al. 2012). Hence, the toxicity of metal oxides towards the environment limits the application of these nanosorbents to the lab, which makes them impractical.

With regards to metal oxides, emphasis needs to be placed on the synthesis of nanomaterials through green techniques. Further, research needs to be directed at the recyclability of other types of nanomaterials, with the exception of magnetic nanoparticles. Magnetic nanoparticles have been proven to be effortlessly separated from water by inducing external magnetic fields. More studies need to be done in exploring the surface chemistry of nanosorbents. The flexible surface structure of nanosorbents can pave the way for a host of various functional groups to be explored and incorporated onto nanomaterials. This in turn allows for potentially improved nanosorbents with good adsorption capacities, stability and recyclability.

Funding The authors are grateful to National Research Foundation and the Sasol Inzalo Foundation for their financial support.

\section{Compliance with ethical standards}

Conflict of interest The authors declare that they have no conflict of interest.

Open Access This article is licensed under a Creative Commons Attribution 4.0 International License, which permits use, sharing, adaptation, distribution and reproduction in any medium or format, as long as you give appropriate credit to the original author(s) and the source, provide a link to the Creative Commons licence, and indicate if changes were made. The images or other third party material in this article are included in the article's Creative Commons licence, unless indicated otherwise in a credit line to the material. If material is not included in the article's Creative Commons licence and your intended use is not permitted by statutory regulation or exceeds the permitted use, you will need to obtain permission directly from the copyright holder. To view a copy of this licence, visit http://creativecommons.org/licenses/by/4.0/.

\section{References}

Aubé B, Zinck J, Eng M (2003) Lime treatment of acid mine drainage in Canada. In Brazil-Canada Seminar on Mine Rehabilitation. Brazil-Canada Seminar on Mine Rehabilitation, Florianópolis $1-12$

Akinwekomi V, Maree JP, Wolkersdorfer C (2017) Using calcium carbonate/hydroxide and barium carbonate to remove sulphate from mine water. Mine Water Environ 36:264-272

Archary MS, Satpathy KK, Panigrahi S, Mohanty AK, Padhi RK, Biwas S, Prabhu RK, Vijayalakshmi S, Panigrahy RC (2017) Concentration of heavy metals in the food chain components of the nearshore coastal waters of Kalpakkam, southeast coast of India. Food Control 72:232-243

Ashok B, Bhagyashree J, Ameeta RK, Smita Z (2010) Banana peel extract mediated novel route for the synthesis of silver nanoparticles. J Colloid Interface Sci 368:58-63

Badruddoza AZM, Shawon ZBZ, Tay WJD, Hidajat K, Uddin MS (2013) $\mathrm{Fe}_{3} \mathrm{O}_{4}$ /cyclodextrin polymer nanocomposites for selective heavy metals removal from industrial wastewater. Carbohydr Polym 91:322-332

Bai Y, Liang YN, Hi X (2017) An eco-friendly approach for heavy metal adsorbent regeneration using $\mathrm{CO}_{2}$ responsive molecular octopus. Chemosphere 185:1157-1163

Bakiya LK, Sudha PN (2012) Adsorption of Copper (II) ion onto chitosan/sisal/banana fiber hybrid composite. J Environ Sci Int 3:1-18

Balouch A, Talpur FN, Kumar A, Shah MT, Mahar AM, Amina, (2019) Synthesis of ultrasonic-assisted lead ion imprinted polymer as a selective sorbent for the removal of $\mathrm{Pb}^{2+}$ in a real water sample. Microchem J 146:1160-1168 
Barrera K, Briso A, Ide V, Martorana L, Montes G, Basualto C, Bormann T, Valenzuela $F$ (2017) Treatment of acidic mine drainage in an adsorption process using calcium silicate modified with $\mathrm{Fe}(\mathrm{III})$. Hydrometallurgy 172:19-29

Buenaño X, Canoira L, Sánchez DM, Costafreda J (2017) Zeolitic tuffs for acid mine drainage (AMD) treatment in Ecuador: breakthrough curves for $\mathrm{Mn}^{2+}, \mathrm{Cd}^{2+}, \mathrm{Cr}^{3+}, \mathrm{Zn}^{2+}$, and $\mathrm{Al}^{3+}$. Environ Sci Pollut Res 24:6794-6806

Beygli RA, Mohaghegh N, Rahimi E (2019) Metal ion adsorption from wastewater by $\mathrm{g}-\mathrm{C}_{3} \mathrm{~N}_{4}$ modified with hydroxyapatite: a case study from Sarcheshmeh acid mine drainage. Res Chem 45:2255-2268

Biswas TK, Yusoff MM, Sarjadi MS, Arshad SE, Musta B, Rahman ML (2019) Synthesis of azobenzene-based ion-imprinted polymers for selective removal of cobalt and copper ions from a mixture of metal ions. Gen Chem 6:1-20

Bitas D, Samanidou V (2020) Chapter 23-Biomedical applications. Handbooks in separation science, liquid-phase extraction, pp 683-723

Bojdi MK, Mohammed B, Najafi M, Bagheri A, Omidi F, Salimi S (2015) Selective and sensitive determination of uranyl ions in complex matrices by ion imprinted polymers-based electrochemical sensor. Electroanalysis 27:2458-2467

Briso A, Quintana G, Ide V, Basualto C, Molina L, Montes G, Valenzuela $F$ (2018) Integrated use of magnetic nanostructured calcium silicate hydrate and magnetic manganese dioxide adsorbents for remediation of an acidic mine water. J Water Process Eng 25:247-257

Castro L, Blázquez ML, González F, Muñoz JA, Ballester A (2018) Heavy metal adsorption using biogenic iron compounds. Hydrometallurgy 179:44-51

Castro RSD, Caetano L, Ferreira G, Padilha PM, Saeki MJ, Zara LF, Martines MAU, Castro GR (2011) Banana peel applied to the solid phase extraction of copper and lead from river water: preconcentration of metal ions with a fruit waste. Ind Eng Chem 50:3446-3451

Chowdhury SR, Yanful EK (2010) Arsenic and chromium removal by mixed magnetite-maghemite nanoparticles and the effect of phosphate on removal. J Environ 91:2238-2247

Christopher FC, Anbalagan S, Kumar PS, Pannerselvam SR, Vaidyanathan VK (2017) Surface adsorption of poisonous $\mathrm{Pb}$ (II) ions from water using chitosan functionalised magnetic nanoparticles. IET Nanobiotechnol 11:433-442

Cui Y, Zhao Y, Tian Y, Zhang W, Lü X, Jiang X (2012) The molecular mechanism of action of bactericidal gold nanoparticles on Escherichia coli. Biomaterials 33:2327-2333

Darroudi A, Chamaz M, Arbab Zavar M, Mofrad Z (2020) Application of ion imprinted polymer synthesized as new sorbent for preconcetration and separation of Thallium (I) and its determination by electrothermalatomic adsorption spectroscopy. IJJCE 39:59-66

Dempsey B, Jeon B (2001) Characteristics of sludge produced from passive treatment of mine drainage. Geochem Explor Environ Anal 1:89-94

Dimapilis EAS, Hsu CS, Mendoza RMO, Lu MC (2018) Zinc oxide nanoparticles for water disinfection. Sustain Environ Res 28:47-56

Dlamini CL, De Kock L, Kefeni KK, Mamba BB, Msagati TAM (2019) Polymeric ion exchanger supported ferric oxide nanoparticles as adsorbents for toxic metal ions from aqueous solutions and acid mine drainage. J Environ Health Sci Eng 9:1-12

Ercan G, Uzunoğlu D, Ergüt M, Özer A (2019) Biosynthesis and characterization of iron oxide nanoparticles from Enteromorpha spp. extract: determination of adsorbent properties for copper (II) ions. Int J Res Eng Technol 3:65-74

Etale A, Tutu H, Drake DC (2016) The effect of silica and maghemite nanoparticles on remediation of $\mathrm{Cu}(\mathrm{II}), \mathrm{Mn}(\mathrm{II})$ - and U(VI) contaminated water by Acutodesmus sp. J Appl Phycol 28:251-260
Etale A, Tavengwa N, Tutu H, Drake DC (2017) Synthesis, characterization, and application of functionalized silica-carbon hybrid nanoparticles for the treatment of acidic $\mathrm{Cu}$ (II)-contaminated water. Clean-Soil Air Water 45:1-17

Feng G, Ma J, Zhang X, Zhang Q, Xiao Y, Ma Q, Wang S (2019) Magnetic natural composite $\mathrm{Fe}_{3} \mathrm{O}_{4}$-chitosan @ bentonite for removal of heavy metals from acid mine drainage. J Colloid Interface Sci 538:132-141

Galhardi J, Bonotto DM (2015) Geochemistry of natural radionuclides associated with acid mine drainage (AMD) in a coal mining area in southern Brazil. J Nucl Sci Technol 9:504-511

Gatabi J, Sarrafi Y, Lakouraj MM, Taghavi M (2020) Facile and efficient removal of $\mathrm{Pb}$ (II) from aqueous solution by chitosan-lead ion imprinted polymer network. Chemosphere 240:1-7

Ge F, Li MM, Ye H, Zhao BX (2012) Effective removal of heavy metal ions $\mathrm{Cd}^{2+}, \mathrm{Zn}^{2+}, \mathrm{Pb}^{2+}, \mathrm{Cu}^{2+}$ from aqueous solution by polymermodified magnetic nanoparticles. J Hazard 366:211-212

Ghasemi E, Heydari A, Sillanpää M (2017) Superparamagnetic $\mathrm{Fe}_{3} \mathrm{O}_{4}$-EDTA nanoparticles as an efficient adsorbent for simultaneous removal of $\mathrm{Ag}(\mathrm{I}), \mathrm{Hg}(\mathrm{II}), \mathrm{Mn}(\mathrm{II}), \mathrm{Zn}(\mathrm{II}), \mathrm{Pb}$ (II) and $\mathrm{Cd}(\mathrm{II})$ from water and soil environmental samples. Microchem J 131:51-56

Gugushe AS, Mpupa A, Nomngongo PN (2019) Ultrasound-assisted magnetic solid phase extraction of lead and thallium in complex environmental samples using magnetic multi-walled carbon nanotubes/zeolite nanocomposites. Microchem J 149:1-8

Gupta B, Kumar N, Panda K, Kanan V, Joshi S, Visoly-Fisher I (2017) Role of oxygen functional groups in reduced graphene oxide for lubrication. Sci Rep 7:1-14

He R, Wang Z, Tan L, Zhong Y, Li W, Xing D, Wei C, Tang Y (2018) Design and fabrication of highly ordered ion imprinted SBA15 and MCM-41 mesoporous organosilicas for efficient removal of $\mathrm{Ni}^{2+}$ from different properties of wastewaters. Microporous Mesoporous Mater 257:212-221

Hennion MC (1999) Solid-phase extraction: method development, sorbents, and coupling with liquid chromatography. J Chromatogr A $856: 3-54$

Hong S, Cannon FS, Hou P, Byrne T, Nieto-Delgado C (2017) Adsorptive removal of sulfate from acid mine drainage by polypyrrole modified activated carbons: effects of polypyrrole deposition protocols and activated carbon source. Chemosphere 184:429-443

Hui KS, Chao CYH, Kot SC (2005) Removal of mixed heavy metal ions in wastewater by zeolite $4 \mathrm{~A}$ and residual products from recycled coal fly ash. J Hazard Mater 127:89-101

Jafaripour NAR, Ghataora GS (2015) Utilisation of residue gas sludge (BOS sludge) for removal of heavy metals from acid mine drainage (AMD). Int J Miner Process 144:90-96

Jha B, Singh DN (2011) A review on synthesis, characterization and industrial application of flyash zeolites. J Mater Educ 33:65-132

Jha B, Singh DN (2016) Fly ash zeolites: Innovations, applications, and directions. Adv Struct Mater 78:1-211

Jia Q, Ma Y, Peng Y, Liu Y, Zhang W (2018) Selective recognition and separation of luteolin based on the molecular imprinted hollow $\mathrm{SnO}_{2}$ and boronate affinity. Chem Eng 342:293-303

Jia C, Zhao J, Lei L, Kang X, Lu R, Chen C, Li S, Zhao Y, Yang Q, Chen Z (2019) Novel magnetically separable anhydride-functionalized $\mathrm{Fe}_{3} \mathrm{O}_{4} @ \mathrm{SiO}_{2} @$ PEI-NTDA nanoparticles as effective adsorbents: synthesis, stability and recyclable adsorption performance for heavy metal ions. RSC Adv 9:9533-9545

Khamirchi R, Hosseini-Bandegharaei A, Alahabadi A, Sivamani S, Rahmani-Sani A, Shahryari T, Anastopoulosf I, Mohammad M, Tran HN (2018) Adsorption property of Br-PADAP-impregnated multiwall carbon nanotubes towards uranium and its performance in the selective separation and determination of uranium in different environmental samples. Ecotoxicol Environ Saf 150:136-143

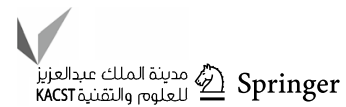


Karagüzel C, Ören Ö, Şahbaz M, Canıeren Ö, Demir U, Şahbaz O (2020) Prediction of acid mine drainage potential of dump sites by using static tests: an application on lignite mine. Arab J Geosci $13: 1-14$

Kumar A, Balouch A, Abdullah AA, Pathan AA (2019) Synthesis, adsorption and analytical applicability of Ni-imprinted polymer for selective adsorption of $\mathrm{Ni}^{2+}$ ions from the aqueous environment. Polym Test 77:1-11

Lakovleva E, Sillanpää M (2013) The use of low-cost adsorbents for wastewater purification in mining industries. Environ Sci Pollut Res 20:7878-7899

Le VT, Tran TKN, Tran DL, Le HS, Doan VD, Bui QD, Nguyen HT (2019) One-pot synthesis of a novel magnetic activated carbon/ clay composite for removal of heavy metals from aqueous solution. J Disper Sci Technol 40:1-16

Li Y, Fang F, Wu M, Kuang Y, Wu H (2018a) Heavy metal contamination and health risk assessment in soil-rice system near Xinqiao mine in Tongling city, Anhui province, China. Hum Ecol Risk Assess Int J 24:743-753

Li Y, Li M, Zhang J, Xu X (2019) Adsorption properties of the double-imprinted electrospun crosslinked chitosan nanofibers. Chin Chem Lett 30:762-766

Li Z, Wang L, Meng J, Liu X, Xu J, Wang F, Brookes P (2018b) Zeolite-supported nanoscale zero-valent iron: new findings on simultaneous adsorption of $\mathrm{Cd}(\mathrm{II}), \mathrm{Pb}(\mathrm{II})$, and $\mathrm{As}(\mathrm{III})$ in aqueous solution and soil. J Hazard 344:1-11

Liu J, Wang H, Li X, Jia W, Zhao Y, Ren S (2017) Recyclable magnetic graphene oxide for rapid and efficient demulsification of crude oil-in-water emulsion. Fuel 189:79-87

Lu H, Qiao X, Wang W, Tan F, Sun F, Xiao Z, Chen J (2015) Effective removal of cadmium ions from aqueous solution using chitosanstabilized nano zero-valent iron. Desalin Water Treat 56:256-265

Lu J, Qin Y, Zhang Q, Wu Y, Cui J, Li C, Wang L, Yan Y (2018) Multilayered ion-imprinted membranes with high selectivity towards $\mathrm{Li}^{+}$based on the synergistic effect of 12-crown-4 and polyether sulfone. Appl Surf Sci 427:931-941

Ma J, Sun M, Zeng Y, Liu Z, Zhang M, Xiao Y, Zhang S (2019) Acetylacetone functionalized magnetic carbon microspheres for the highly-efficient adsorption of heavy metal ions from aqueous solutions. RSC Adv 9:3337-3344

Madzivire G, Maleka RM, Tekere M, Petrik LF (2019) Cradle to cradle solution to problematic waste materials from mine and coal power station: acid mine drainage, coal fly ash and carbon dioxide. J Water Process Eng 30:1-8

Mahdi HA, Sregey K, Abbas AK (2017) Catalytic cracking of vacuum gas oil by using the aerosol nanocatalysison new modification catalyst WO3/Si-Zr. J Pet Sci Res Stud 14:67-79

Maia LFO, Hott RC, Ladeira PCC, Batista BL, Andrade TG, Santos MS, Faria MCS, Oliviera LCA, Montiero DS, Pereira MC, Rodrigues JL (2019) Simple synthesis and characterization of 1-Cystine functionalized $\delta$-FeOOH for highly efficient $\mathrm{Hg}$ (II) removal from contamined water and mining waste. Chemosphere 215:422-431

Masoumi F, Sarabadani P, Khorrami AR (2019) Synthesis, characterization and application of a new nano-structured samarium (III) ion-imprinted polymer. Polym Bull 76:5499-5516

Masukume M, Onyango MS, Maree JP (2017) Performance characteristics of synthetic zeolite F9 in treating high iron and manganese acid mine drainage. EEMJ 16:2255-2265

Méndez-Romero UA, Pérez-García SA, Xu X, Wang E, Licea-Jiménez L (2019) Functionalized reduced graphene oxide with tunable band gap and good-solubility in organic solvents. Carbon 146:491-502

Mirza AU, Kareem A, Nami SAA, Bhat SA, Mohammad A, Nishat N (2019) Malus pumila and Juglen regia plant species mediated zinc oxide nanoparticles: synthesis, spectral characterization, antioxidant and antibacterial studies. Microb Pathog 129:233-241

Mobasherpour I, Salahi E, Pazouki M (2012) Comparative of the removal of $\mathrm{Pb}^{+2}, \mathrm{Cd}^{+2}$ and $\mathrm{Ni}^{+2}$ by nano crystallite hydroxyapatite from aqueous solutions: adsorption Isotherm Study. Arab J Chem 5:439-446

Moreira RF, Vandresen S, Luiz DB, José HJ, Puma GL (2017) Adsorption of arsenate, phosphate and humic acids onto acicular goethite nanoparticles recovered from acid mine drainage. JECE 5:652-659

Mokgehle TM, Gitari WM, Tavengwa NT (2019) Synthesis of di-carboxylic acid functionalized zeolites from coal fly ash for Cd (II) removal from acid mine drainage using column studies approach. J Environ Chem Eng 7:1-9

Mohan D, Chander S (2006) Removal and recovery of metal ions from acid mine drainage using lignite-a low cost sorbent. J Hazard Mater 137:1545-1553

Mou Q, Leung PHM (2017) Differential expression of virulence genes in Legionella pneumophila growing in Acanthamoeba and human monocytes. Virulence 9:185-196

Mulopo J, Motaung S (2014) Carbothermal reduction of barium sulfate-rich sludge from acid mine drainage treatment. Mine Water Environ 33:48-53

Nekhunguni PM, Tavengwa NT, Tutu H (2017a) Investigation of As (V) removal from acid mine drainage by iron (hydr) oxide modified zeolite. J Environ Manage 197:550-558

Nekhunguni PM, Tavengwa NT, Tutu H (2017b) Sorption of uranium (VI) onto hydrous ferric oxide-modified zeolite: assessment of the effect of $\mathrm{pH}$, contact time, temperature, selected cations and anions on sorbent interactions. J Environ Manage 204:571-582

Nordstrom DK, Blowes DW, Ptacek CJ (2015) Hydrogeochemistry and microbiology of mine drainage: an update. J Appl Geochem 57:3-16

Nqombolo A, Mpupa A, Gugushe AS, Moutloali RM, Nomngongo PN (2019) Adsorptive removal of lead from acid mine drainage using cobalt-methylimidazolate framework as an adsorbent: kinetics, isotherm, and regeneration. Environ Sci Pollut Res 26:3330-3339

Othman A, Sulaiman A, Sulaiman SK (2017) The use of hydrated lime in acid mine drainage treatment. AIP Conf Proc 1847:1-7

Oyewo OA, Onyango MS, Wolkersdorfer C (2018) Lanthanides removal from mine water using banana peels nanosorbent. Int $\mathrm{J}$ Environ Sci Te 15:1265-1274

Pakdel PM, Peighambardous SJ (2018) A review on acrylic based hydrogels and their applications in wastewater treatment. J Environ Manage 217:123-143

Piletsky S, Piletskaya EV, Sergeyeva T, El'Skayai A, Panusyak T (1999) Molecularly imprinted self-assembled films with specificity to cholesterol. Sens Actuators B 60:216-220

Prasad BB, Jauhari D (2015) Double-ion imprinted polymer @ magneticnanoparticles modified screen printed carbon electrode for simultaneousanalysis of cerium and gadolinium ions. Anal Chim Acta 875:83-91

Rahimi E, Mohaghegh N (2017) New hybrid nanocomposite of copper terephthalate MOF-graphene oxide: synthesis, characterization and application as adsorbents for toxic metal ion removal from Sungun acid mine drainage. Environ Sci Pollut Res Int 24:22353-22360

Ren Y, Zhang M, Zhao D (2008) Synthesis and properties of magnetic $\mathrm{Cu}$ (II) ion imprinted composite adsorbent for selective removal of copper. Desalination 228:135-149

Ren YM, Yang J, Ma WQ, Ma J, Feng J, Liu XL (2014) The selective binding character of a molecular imprinted particle for Bisphenol A from water. Water Res 50:90-100 
Rios CA, Williams CD, Roberts CL (2008) Removal of heavy metals from acid mine drainage (AMD) using coal fly ash, natural clinker and synthetic zeolites. J Hazard Mater 156:23-35

Rodríguez C, Tapia C, Leiva-Aravena E, Leiva E (2020) Graphene oxide- $\mathrm{ZnO}$ nanocomposites for removal of aluminum and copper ions from acid mine drainage wastewater. Int J Environ Res Public Health 17:1-18

Ryu S, Naidu G, Johir MAH, Choi Y, Jeong S, Vigneswaran S (2019) Acid mine drainage treatment by integrated submerged membrane distillation-sorption system. Chemosphere 218:955-965

Sahu UK, Sahu S, Mahapatra SS, Patel RK (2017) Cigarette soot activated carbon modified with $\mathrm{Fe}_{3} \mathrm{O}_{4}$ nanoparticles as an effective adsorbent for As (III) and As (V): material preparation, characterization and adsorption mechanism study. J Mol Liq 243:395-405

Sadani M, Rasolevandi T, Azarpira H, Mahvi AH, Ghaderpoori M, Mohseni SM, Atamaleki A (2020) Arsenic selective adsorption using a nanomagnetic ion imprinted polymer: optimization, equilibrium, and regeneration studies. J Mol Liq 317:1-12

Şarkaya K, Bakhshpour M, Denizli A (2019) $\mathrm{Ag}^{+}$ions imprinted cryogels for selective removal of silver ions from aqueous solutions. Sep Purif Technol 54:1-13

Shakerian F, Kim KH, Kwon E, Szulejko JE, Kumar P, Dadfarnia S, Shabani HAM (2016) Advanced polymeric materials: synthesis and analytical application of ion imprinted polymers as selective sorbents for solid phase extraction of metal ions. Trends Anal Chem 83:55-69

Shabalala AN, Basitere M (2020) Interactive relationship between cementitious materials and acid mine drainage: their effects on Chromium Cr (VI) removal. Minerals 10:1-17

Shakya M, Rene ER, Nancharaiah YV, Lens PNL (2018) Fungal-based nanotechnology for heavy metal removal. In: Gothandam K, Ranjan S, Dasgupta N, Ramalingam C, Lichtfouse E (eds) Nanotechnology, food security and water treatment. Environmental Chemistry for a Sustainable World, pp 229-253

Sukati BH, De Jager PC, Annandale JG, Tanner PD (2018) The hazardous status of high density sludge from acid mine drainage neutralization. Sustainability 10:1-18

Sun D, Zhu Y, Meng M, Qiao Y, Yan Y, Li C (2017) Fabrication of highly selective ion imprinted macroporous membranes with crown ether for targeted separation of lithium ion. Sep Purif Technol 175:19-26

Taghizadeh M, Hassanpour S (2017) Selective adsorption of Cr (VI) ions from aqueous solutions using a $\mathrm{Cr}(\mathrm{VI})$ imprinted polymer supported by magnetic multiwall carbon nanotubes. Polymer 132:1-11

Tian N, Wu J, Wang J, Dai W (2019) Development of a novel coreshell magnetic $\mathrm{Fe}_{3} \mathrm{O}_{4} @ \mathrm{CMC} @ \mathrm{ZIF}-8-\mathrm{OH}$ composite with outstanding Rubidium-ion capacity. J Chem Eng Data 64:5716-5724

Turan NG, Ozgonenel O (2013) The design and implementation of adsorptive removal of $\mathrm{Cu}$ (II) from leachate using adaptive neural fuzzy interface system. Sci World J 2013:1-9

Vilardi G, Ochando-Pulido JM, Verdone N, Stoller M, Di-Palma L (2018) On the removal of hexavalent chromium by olive stones coated by iron-based nanoparticles: equilibrium study and chromium recovery. J Clean Prod 190:200-210
Vilela D, Parmar J, Zeng Y, Zhao Y, Sánchez S (2016) Graphenebased microbots for toxic heavy metal removal and recovery from water. Nano Lett 16:2860-2866

Wang C, Zhao J, Wang S, Zhang L, Liu N, Zhang B (2019a) Selective capture models and mechanisms of $\mathrm{Pb}$ (II) from wastewater using tannic-functionalized nickel-iron oxide nanoparticles. Colloids Surf A Physicochem Eng Asp 570:265-273

Wang L, Li J, Wang J, Guo X, Wang X, Choo J, Chen L (2019b) Green multi-functional monomer based ion imprinted polymers for selective removal of copper ions from aqueous solution. $\mathbf{J}$ Colloid Interface Sci 541:376-386

Wongcharee S, Aravinthan V, Erdei L, Sanongraj W (2017) Use of macadamia nut shell residues as magnetic nanosorbents. Int Biodeterior Biodegradation 124:276-287

Xu H, Yuan H, Yu J, Lin S (2019) Study on the competitive adsorption and correlational mechanism for heavy metal ions using the carboxylated magnetic iron oxide nanoparticles (MNPs-COOH) as efficient adsorbents. Appl Surf Sci 473:960-966

Xu H, Shi ZX, Tong YX, Li GR (2018) Porous microrod arrays constructed by carbon-confined $\mathrm{NiCo} @ \mathrm{NiCoO}_{2}$ core@ shell nanoparticles as efficient electrocatalysts for oxygen evolution. Adv Mater 30:1-8

Xu L, Huang YA, Zhu QJ, Ye C (2015) Chitosan in molecularlyimprinted polymers: current and future prospects. Int J Mol 16:18328-18347

Yan X, Meng J, Hu X, Feng R, Zhou M (2019) Synthesis of thiolfunctionalized mesoporous silica nanoparticles for adsorption of $\mathrm{Hg}^{2+}$ from aqueous solution. J Sol-Gel Sci Techn 89:617-622

Yang L, Hu J, Wu W, Tang J, Ding K, Li J (2016) In situ $\mathrm{NH}_{2}$-functionalized graphene oxide $/ \mathrm{SiO}_{2}$ composites to improve $\mathrm{Cu}(\mathrm{II})$ removal from ammoniacal solutions. Chem Eng 306:77-85

Yuan G, Tu H, Liu J, Zhao C, Liao J, Yang Y, Yang J, Liu N (2018) A novel ion-imprinted polymer induced by the glycylglycine modified metal-organic framework for the selective removal of Co(II) from aqueous solutions. Chem Eng 333:280-288

Yusof NF, Mehamod FS, Mohd Suah FB (2019) Fabrication and binding characterization of ion imprinted polymers for highly selective $\mathrm{Co}^{2+}$ ions in an aqueous medium. J Environ Chem Eng 7:1-9

Zheng X, Zhang Y, Bian T, Zhang Y, Li Z, Pan J (2020) Oxidized carbon materials cooperative construct ionic imprinted cellulose nanocrystals films for efficient adsorption of Dy(III). Chem Eng 381:1-10

Zhang M, Helleur R, Zhang Y (2015) Ion-imprinted chitosan gel beads for selective adsorption of $\mathrm{Ag}+$ from aqeous solutions. Carbohydr Polym 130:206-212

Zhang X, Wang H, Sun X, Shang H, Di Y, Zhao Z (2019) Preparation and properties of thermo-sensitive surface $\mathrm{Pb}$ (II) ion-imprinted polymers. Colloids Surf A Physiol Eng Asp 577:138-146

Zhu G, Cheng G, Wang L, Yu W, Wang P, Fan J (2019) A new ionic liquid surface imprinted polymer for selective solid phase extraction and determination of sulfonamides in environmental samples. J Sep Sci 42:725-735 